\title{
Perancangan Sistem Transmisi 2WD dan 4WD serta Analisis Karakterisitik Traksi pada Mobil Multiguna Pedesaan
}

\author{
Mahmud Rifai dan I Nyoman Sutantra \\ Departemen Teknik Mesin, Fakultas Teknologi Industri \\ Institut Teknologi Sepuluh Nopember (ITS) 60111 Indonesia \\ e-mail: tantra@me.its.ac.id
}

\begin{abstract}
Abstrak-Mobil multiguna pedesaan merupakan mobil yang ditunjukan untuk dapat membantu kegiatan perekonomian di daerah pedesaan, misalnya mengangkut hasil pertanian, perkebunan, mengangkut orang dan masih banyak lagi. Mobil multiguna pedesaan dirancang untuk dioperasikan diwilayah pedesaan yang tentunya memiliki medan jalan lebih beragam daripada medan jalan pada umumnya. Medan jalan yang dimaksud seperti tanjakan maupun turunan curam, jalan berbatu, jalan berpasir, jalan yang basah, jalan sempit yang banyak ditemui didaerah perbukitan, pegunungan, dan pesisir pantai. Dalam penelitian ini dilakukan sebuah perancangan dan analisis sistem transmisi pada mobil multiguna pedesaan. Mobil multiguna pedesaan yang baru dirancang menggunakan engine Diesel. Perhitungan yang dilakukan meliputi dua tahap, untuk tahap perhitungan yang pertama adalah menghitung besar dari gaya hambat yang terjadi pada kendaraan, selanjutnya menghitung rasio transmisi dan tingkat transmisi yang akan digunakan pada mobil multiguna pedesaan. Selanjutnya setelah didapatkan parameter transmisi maka dilakukan perancangan dari tiap komponen sistem transmsisi. Dari hasil penelitian, untuk dapat menempuh medan tanjakan maksimal dan kecepatan maksimal yang diinginkan maka rasio transmisi yang digunakan berturut-turut $8.4,4,2$, dan 1 untuk rasio gigi 1 sampai 4. Dengan rasio tersebut Mobil Multiguna Pedesaan akan memiliki kemampuan menanjak maksimal kemiringan jalan $30^{\circ}$ dan kecepatan maksimal $69.2 \mathrm{~km} / \mathrm{jam}$. Penggunaan sistem Transfer Case memungkinkan kendaraan untuk beroperasi mode 4WD sehingga kemampuan melaju kendaraan pada saat kontur jalan yang buruk menjadi meningkat dan mampu digunakan untuk memindah daya engine untuk memutar mesin produksi dengan lebih terintegrasi.
\end{abstract}

Kata Kunci- Gaya Hambat, Diesel, Transmisi, Traksi.

\section{PENDAHULUAN}

$\mathrm{K}^{\mathrm{B}}$ EMAJUAN teknologi transportasi di Indonesia memunculkan berbagai jenis kendaraan yang mampu memudahkan pekerjaan masyarakat. Salah satu sektor masyarakat yang perlu diperhatikan adalah masyarakat di pedesaan. Banyaknya pedesaan yang ada tersebut menuntut adanya teknologi transportasi yang mampu untuk meningkatkan sektor perekonomian masyarakat pedesaan. Maka dari itu dibuatlah Mobil Multiguna pedesaan oleh Departemen Teknik Mesin ITS.

Mobil Multiguna Pedesaan buatan Departemen Teknik Mesin ITS dirancang untuk dioperasikan diwilayah pedesaan di Indonesia guna menawarkan solusi sebagai kendaraan yang dapat digunakan sebagai alat bantu berbagai berbagai macam proses produksi pertanian, perkebunan, peternakan dan perikanan seperti pengangkutan, penggilingan maupun yang lainnya.
Alat transportasi Mobil multiguna pedesaan dirancang harus mampu dioperasikan diwilayah pedesaan yang mempunyai medan jalan yang lebih beragam daripada medan jalan pada umumnya. Medan jalan yang dimaksud seperti tanjakan dan turunan yang curam, jalan berbatu, jalan berpasir, jalan yang basah, jalan sempit yang banyak ditemui didaerah perbukitan, pegunungan, dan pesisir pantai. Kondisi demikian membuat Mobil Multiguna pedesaan tidak cukup hanya sebagai mobil yang dapat mengangkut sekaligus mengolah hasil pertanian, akan tetapi mobil akan lebih sempurna jika dirancang dapat melewati medan sulit yang ada secara optimal.

Jalan pada umumnya menurut standart Bina Marga dirancang memiliki gradient sekitar 3-4 \%. Akan tetapi untuk kasus khusus seperti daerah pegunungan gradient kemiringan jalan bisa ditemui hingga $26 \%[1]$. Pada perancangan ini diharapkan kendaraan mobil multiguna pedesaaan dapat menanjak hingga gradient kemiringan ekstrim karena memang kondisi jalan yang masih buruk di daerah pedesaan di Indonesia. Daerah operasi mobil pada daerah pedesaan juga membuat factor kebutuhan akan kecepatan yang diinginkan berbeda dengan mobil penumpang pada umumnya. Sehingga kendaraan tidak terlalu membutuhkan kecepatan yang tinggi melainkan cukup dengan kecepatan yang rendah berkisar antara $60 \mathrm{~km} / \mathrm{jam}$.

Pada studi kali ini penulis melakukan sebuah perancangan terhadap sistem transmisi pada mobil multiguna pedesaan untuk memaksimalkan sistem Power Train sehingga dapat melalui medan atau jalan daerah terpencil lebih optimal. Sedangkan Engine yang digunakan pada Mobil Multiguna Pedesaan ini adalah engine Diesel dan dimensi dari chasis kendaraan yang dipakai mengikuti dari dimensi Mobil multiguna pedesaan yang sudah ada.

\section{URAIAN PENELITIAN}

Analisis dimulai dengan memperhitungkan gaya hambat yang terjadi pada kendaraan seperti yang ditunjukkan pada gambar 1. Gaya hambat yang diperhitungkan adalah gaya hambat rolling, gaya hambat angin, gaya hambat tanjakan[2]. Sehingga dari ketiga gaya hambat tersebut didapat gaya hambat total berdasarkan variasi tanjakan. Untuk menghitung gaya hambat rolling menggunakan persamaan :

$$
\begin{aligned}
& \mathrm{R}_{\mathrm{r}}=\mathrm{f}_{\mathrm{r}} \mathrm{W} \\
& \mathrm{f}_{\mathrm{r}}=\mathrm{f}_{\mathrm{o}}+\mathrm{f}_{\mathrm{s}}\left(\frac{V}{100}\right)^{2,5}
\end{aligned}
$$

Dimana $f_{r}$ adalah koefisien rolling, $f_{o}$ dan $f_{s}$ adalah koefisien yang bergantung pada tekanan ban kendaraan dan 
$W$ adalah berat kendaraan. untuk menghitung gaya hambat angin menggunakan persamaan :

$$
\mathrm{R}_{\mathrm{a}}=\frac{1}{2} \times C d \times A f \times V a^{2}
$$

Dimana $R a=$ hambatan aerodinamika, $\rho=$ massa jenis udara, $C_{d}=$ koefisien drag, $A f=$ luas frontal kendaraan, $V a=$ kecepatan relative angin. Dan untuk gaya hambat tanjakan mengunakan persamaan :

$$
\mathrm{R}_{\mathrm{g}}=\mathrm{W} \sin \theta
$$

Dimana $\theta$ adalah sudut tanjakan. Selanjutnya dihitung gaya hambat total pada kendaraan menggunakan persamaan :

$$
\begin{aligned}
& F_{r}=R_{r}+R_{a}+R_{g} \\
& F_{r}=f_{r} . W \cos \theta_{\text {max }}+\frac{1}{2} \rho C_{d} A f \mathrm{Va}^{2}+W \sin \theta_{\text {max }}
\end{aligned}
$$

dimana $F_{r}$ adalah gaya hambat total.

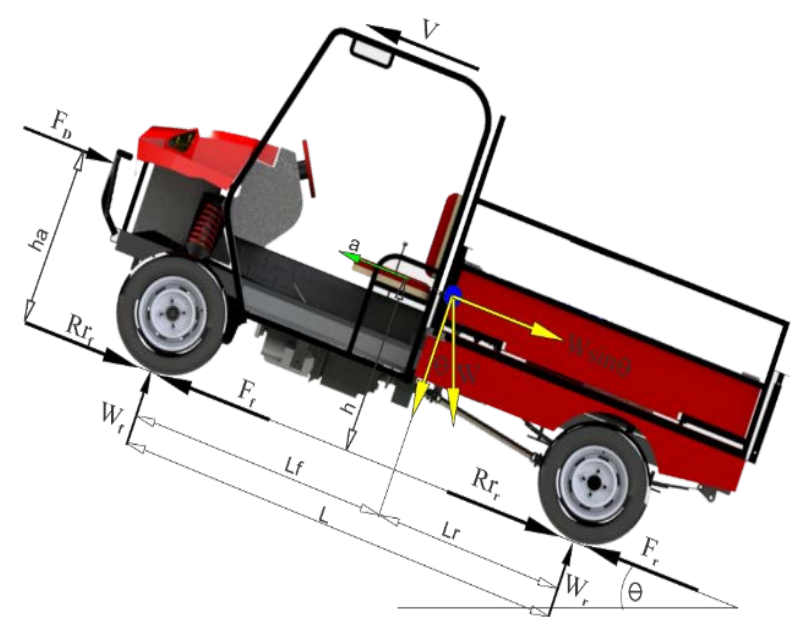

Gambar 1. Dinamika kendaraan mobil multiguna pedesaan

Setelah di dapatkan gaya hambat kendaraan maka bisa didapatkan kebutuhan power untuk kendaraan dengan menggunakan persamaan :

$$
\mathrm{P}=\text { Fr } \mathrm{x} \mathrm{V}
$$

Selanjutnya menentukan sistem transmisi kendaraan yang berfungsi mengkonversi torsi dan kecepatan dari sumber penggerak menjadi torsi dan kecepatan yang berbeda-beda kemudian diteruskan ke penggerak akhir. Langkah pertama menghitung rasio transmisi adalah menentukan rasio transmisi tingkat pertama menggunakan persamaan :

$$
i_{1}=\frac{F t x r}{T_{m} \times i_{g} \times \eta_{t}}=\frac{\left(W \sin \Theta_{\max }+f_{r} \cdot W+R a\right) r}{T_{m} \times i_{g} \times \eta_{t}}
$$

dimana Ft adalah gaya torsi kendaraan, Tm adalah torsi engine, ig adalah rasio gardan yang dipakai, $\eta_{t}$ adalah efisisensi dari sistem transmisi.

Setelah itu, menghitung rasio transmisi terkecil dan tingkat transmisi yang digunakan pada kendaraan. Rasio transmisi terkecil menggunakan persamaan

$$
i_{m}=\frac{F t \times r}{T \times i_{g} \times \eta_{t}}=\frac{\left(f_{r} \cdot W+\frac{1}{2} \rho \cdot C_{d} A_{f . V_{m}}\right) r}{T \times i_{g} \times \eta_{t}}
$$

Dengan demikian, nlai faktor $K_{g}$ dapat ditentukan dengan dengan persamaan 10. Selanjutnya, nilai $\mathrm{Kg}$ tersebut digunakan untuk menentukan nilai rasio selanjutnya.

$$
K_{g}=\left(\frac{\mathrm{i}_{\mathrm{n}}}{\mathrm{i}_{1}}\right)^{\frac{1}{\mathrm{n}-1}}
$$

Langkah berikutnya yaitu menghitung gaya dorong yang dihasilkan oleh engine yang kemudiaan disalurkan melalui sistem transmisi sehingga akhirnaya dapat menggerakkan roda. Untuk menghitung gaya dorong yang mampu dihasilkan kendaraan dapat menggunakan persamaan :

$$
F t=\frac{i t \cdot i g \cdot M e}{r} \eta t
$$

Setelah didapat gaya dorong kendaraan maka dapat diperoleh hasil karakteristik power dari kendaraan dengan menggunakan persamaan :

$$
\mathrm{Pt}=\mathrm{Ft} \times \mathrm{V}
$$

Setelah didapat data rasio dari setiap komponen dan analisis karakteristik traksi sistem transmisi untuk selanjutnya digunakan dalam perancangan setiap elemen mesin untuk setiap komponen dari sistem trasmisi. Untuk perancngan elemen mesin dari kompone sistem transmisi, standar ANSI/AGMA 2001-D04 digunakan dalam perancangan komponen spur gear yang terdiri dari analisis spur gear bending dan spur gear wear[3]. Maximum Distortion Energy Theory, Von Misses, DE Goodman digunakan dalam perancangan komponen poros[4]. Perancangan Splines dan pemilihan komponen bearing yang dipakai mengacu pada katalog SKF.

Data- data yang yang dibutuhkan dalam proses perhitungan didapat dari studi lapangan maupun dari studi literatur, sedangkan untuk konstanta-konstanta yang diperlukan diambil dari handbook menyesuiakan dengan bentuk kemiripan kerja kendaraan.

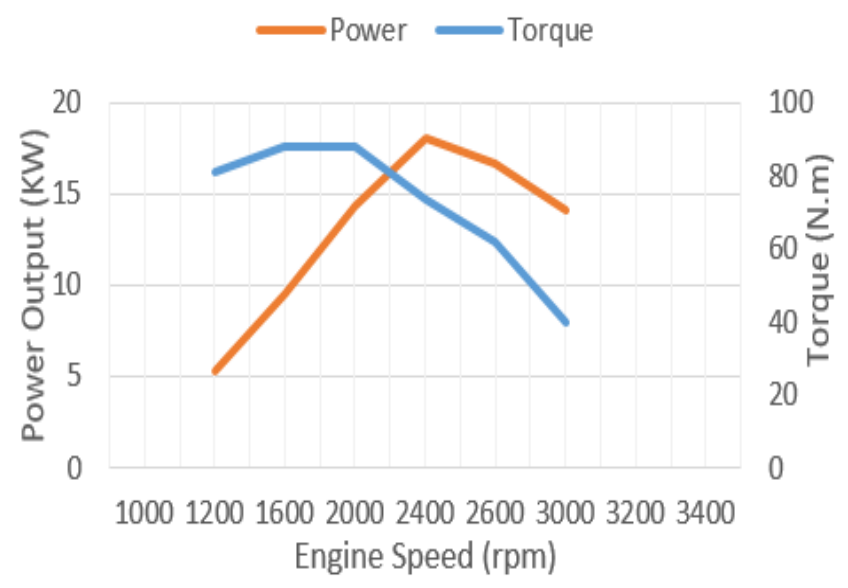

Gambar 2. Performa engine Diesel DDI 2700 H

Untuk data kendaraan berupa kinerja engine sendiri yang meliputi torsi engine, power engine, putaran dan kecepata engine diperoleh dari grafik performa engine Diesel DDI $2700 \mathrm{H}$.

\section{ANALISIS DATA DAN PEMBAHASAN}

\section{A. Perhitugan Gaya Hambat Kendaraan}

Dengan menggunakan persamaan 6 , maka didapatkan gaya hambat total pada kendaraan mobil multiguna pedesaan pada gambar 3 . 


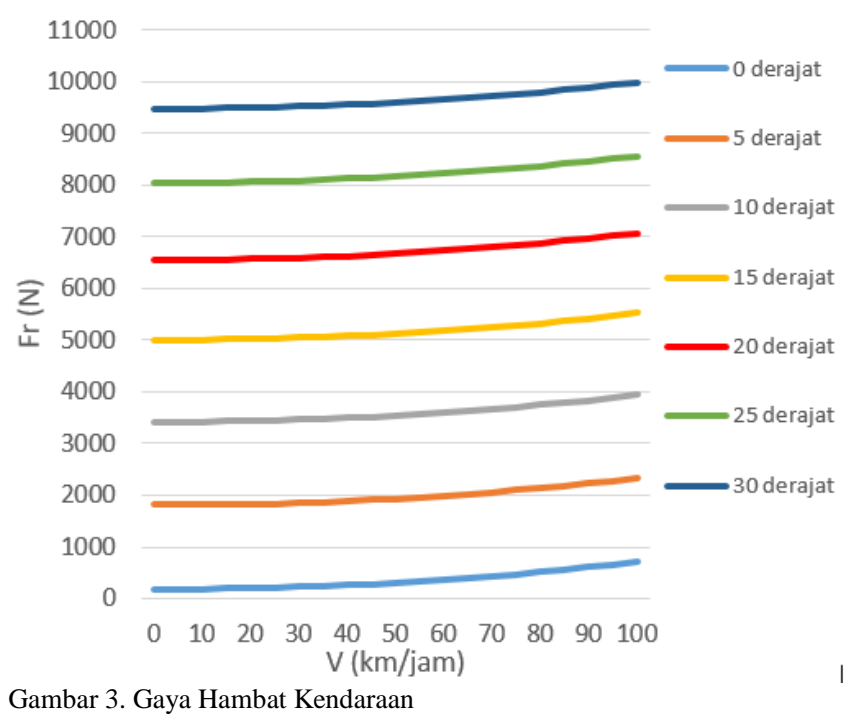

Setelah didapatkan gaya hambat kendaraan maka dengan menggunakan persamaan 7 maka dapat didapatkan kebutuhan power kendaraan pada gambar 4.

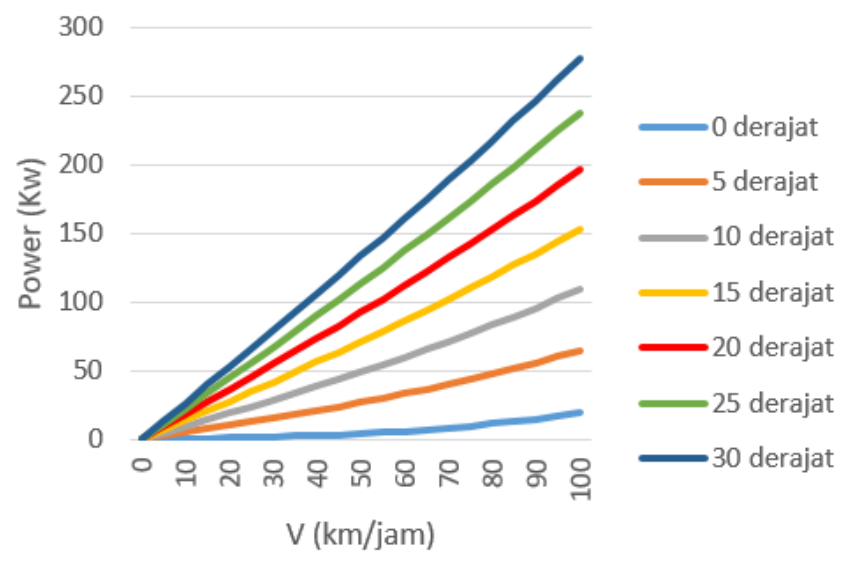

Gambar 4. Kebutuhan power kendaraan

\section{B. Perhitungan Rasio dan Tingkat Transmsisi Kendaraan}

Penentuan nilai dan tingkatan dari rasio setiap tingkatan gigi ditentukan menggunakan metode geometrical step, dimana rasio terbesar ditentukan dari kemampuan tanjakan maksimal kendaraan yang diinginkan dengan menggunakan persamaan 8 , sedangkan rasio minimal ditentukan dari kecepatan maksimal yang diinginkan dengan menggunakan persamaan 9. Setelah itu, ditentukan tingkat transmisi yang tepat untuk digunakan pada mobil multiguna pedesaan menggunakan persamaan 10. Setelah dilakukan perhitungan maka didapatkan tingkat transmisi yang tepat untuk mobil multiguna pedesaan adalah dengan 4 tingkat kecepatan. Tabel 1 menjelaskan nilai rasio dan tingkat transmisi.

Tabel 1.

\begin{tabular}{cc}
\multicolumn{2}{c}{ Data rasio dan tingkat transmisi } \\
\hline Tingkat Transmisi & Rasio \\
\hline 1st gear & 8.4 \\
2nd gear & 4 \\
3th gear & 2 \\
4th gear & 1 \\
\hline
\end{tabular}

\section{Analisis Karakteristik Traksi dan Power Kendaraan}

Setelah dilakukan perhitungan gaya hambat dan gaya traksi kendaraan maka didapatkan analisis traksi kendaraan mobil multiguna pedesaan pada saat berjalan. Pada gambar 5 dapat dilihat perbandingan gaya hambat dan gaya traksi kendaraan dibandingkan kecepatan laju kendaraan. Tampak pada grafik bahwa gaya traksi terbesar kendaraan mampu melawan gaya hambat kendaraan sampai sudut tanjak $30^{\circ}$, sehingga mobil multiguna pedesaan memiliki kemampuan maksimal menanjak sampai kemiringan $30^{\circ}$. Selain itu, tampak pada grafik juga bahwa pada saat kondisi jalan mendatar mobil multiguna pedesaan mampu mencapai kecepatan maksimum sampai 69,2 km/jam.

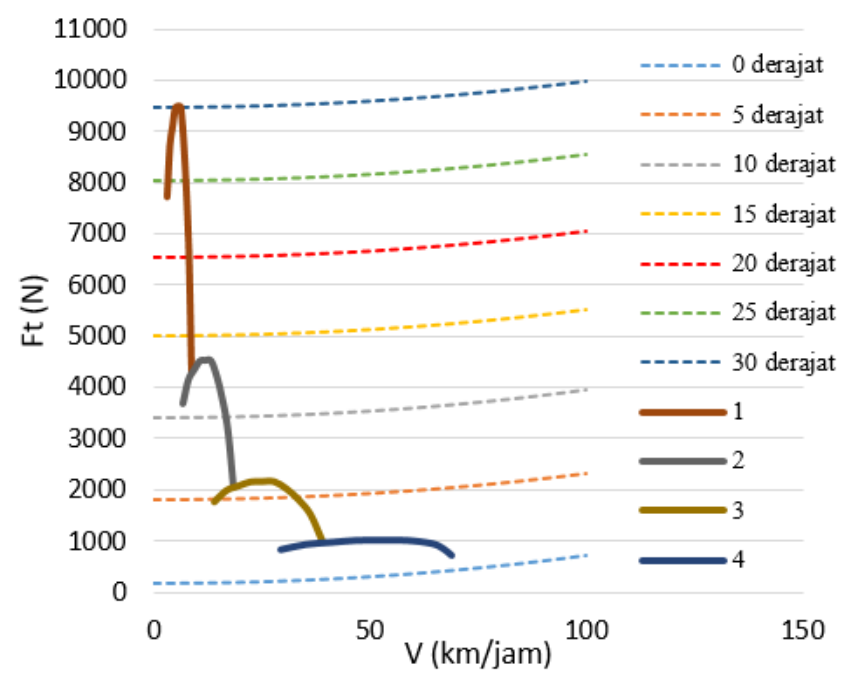

Gambar 5. Karakteristik Traksi kendaraan mobil multiguna pedesaaan

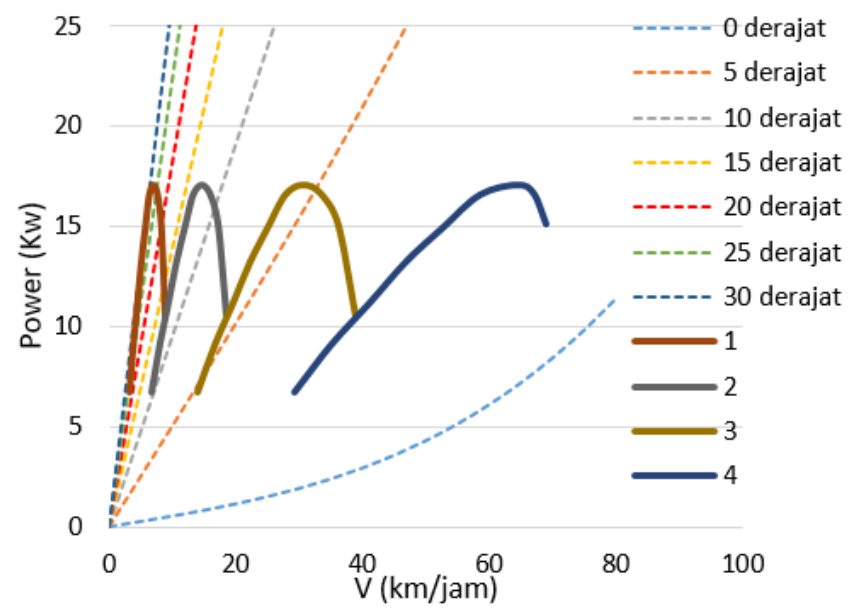

Gambar 6. Karakteristik power mobil multiguna pedesaan

Berdasarkan gambar 6, dapat dilihat perbandingan antara kebutuhan power untuk melawan gaya hambat kendaraan dengan power yang dihasilkan oleh engine. Pada tingkat transmisi pertama power dari engine seluruhnya digunakan untuk menanjak pada kemiringan $30^{\circ}$ dengan kecepatan maksimal 9,7 km/jam. Dan pada jalan mendatar kecepatan maksimum yang mampu dicapai pada tingkat kecepatan 4 adalah $69,2 \mathrm{~km} / \mathrm{jam}$, hal ini karena power yang dihasilkan engine sesuai dengan power yang dibutuhkan untuk melawan gaya hambat.

\section{Spin Area Kendaraan}

Detail pengaruh mode operasi 4 Wheel Drive dalam meningkatkan performa kendaraan dapat dilihat pada gambar 4. Tampak pada gambar 7 saat mode berkendara 2WD pada kontur jalan aspal batas spin area masih jauh dari grafik traksi kendaraan sehingga saat melaju di jalan aspal mendatar maupun pada jalan aspal yang memiliki kemiringan kendaraan akan aman tidak mengalami slip pada ban. 


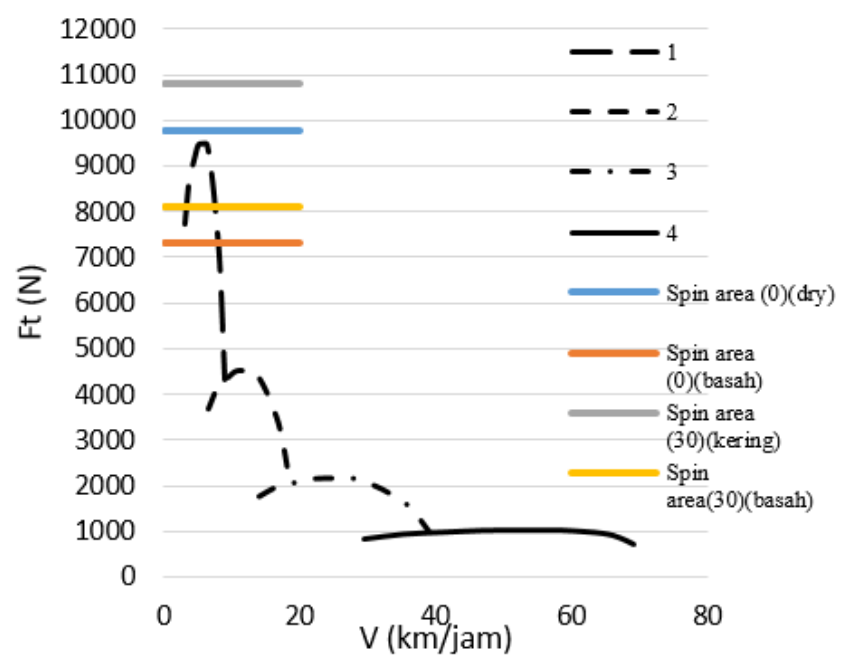

(a)

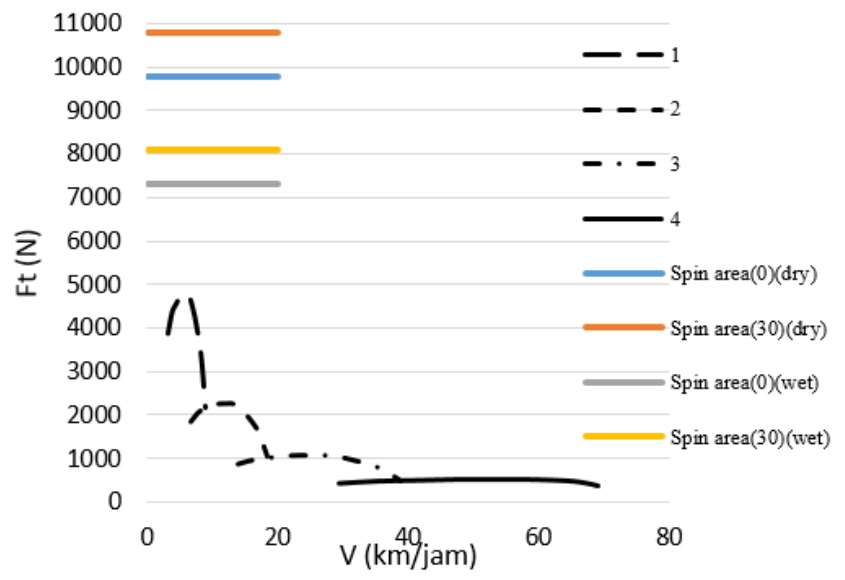

(b)

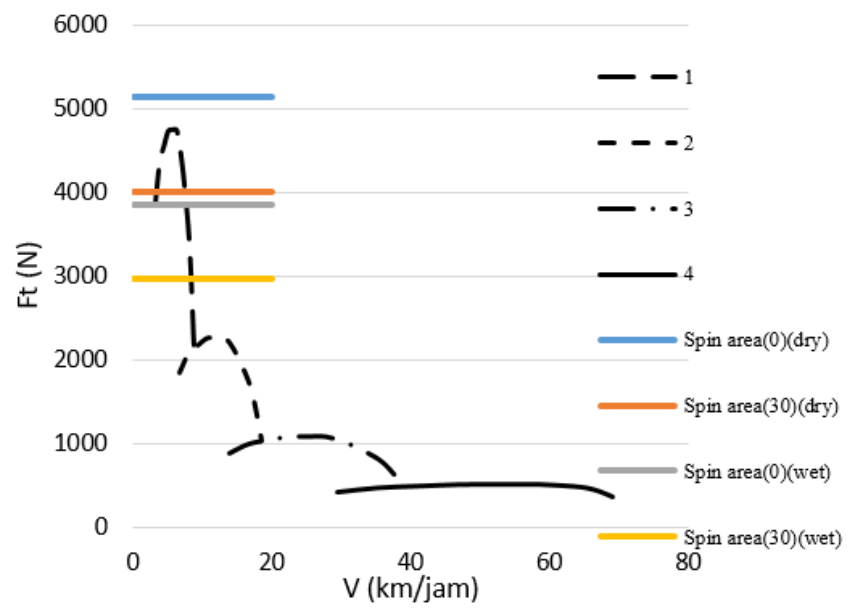

(c)

Gambar 7. Grafik traksi \& spin area pada jalan aspal (a)2WD; (b) 4WD (rare tire); (c)4WD (front tire)

Kondisi akan berbeda jika kendaraan melewati kontur jalan tanah, saat kondisi jalan tanah basah maupun terdapat kemiringan nilai gaya traksi kendaraan berada diatas spin area sehingga mobil akan kehilangan gaya dorong karena roda mengalami slip. Begitu pula pada saat jalan berlumpur atau pasir kendaraan tidak akan mampu berjalan akibat slip karena pada kondisi ini hampir semua gaya traksi yang dihasilakan berada diatas spin area. Jadi pada kondisi jalan tanah maupun berlumpur kendaraan lebih baik beroperasi dengan mode 4WD karena gaya traksi yang dihasilkan hampir semua masih dibawah batas spin area.

\section{E. Sistem Transmisi}

Detail rancangan dari sistem transmisi dapat dilihat gambar 8. Sistem transmisi yang digunakan terdiri dari 4 tingkat dan gigi mundur. Tipe dari transmisi adalah 2 stage. Dan menggunakan sistem synchromesh untuk memperhalus proses perpindahan gigi.

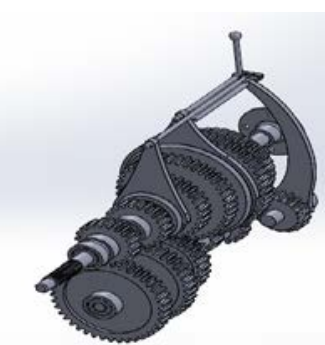

(a)

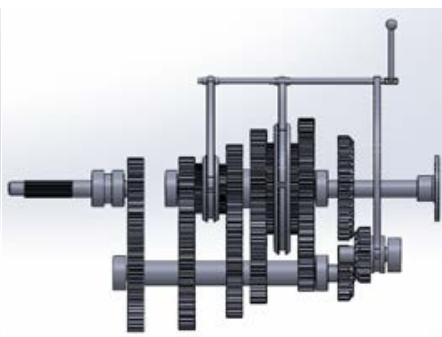

(b)
Gambar 8. Rancangan sistem transmisi Mobil multiguna pedesaaan dengan 4 tingkat kecepatan dan gigi mundur (a)tampak isometric ; (b)tampak samping

\section{F. Sistem Transfer Case}

Detail rancangan dari sistem transfer case dapat dilihat pada gambar 9. Sistem transfer case dirancang dengan 2 tuas, tuas yang pertama untuk merubah mode kendaraan 2WD dan 4WD. Sedangkan tuas kedua digunakan untuk memindahkan mode operasi berkendara atau saat mode produksi. Sistem transfer case tidak dilengkapi dengan sistem synchromesh sehingga setiap ingin melakukan perpindahan mode, mobil harus dalam keadaan berhenti.

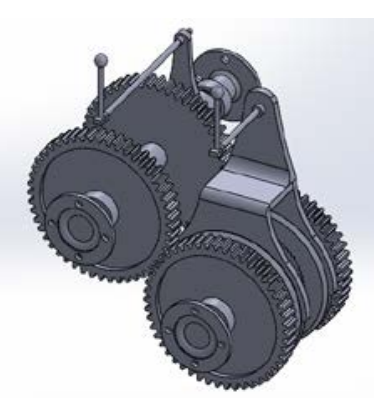

(a)

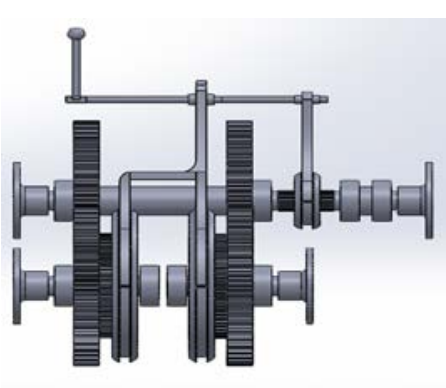

(b)
Gambar 9. Rancangan sistem transfer case mobil multiguna pedesaan (a)tampak isometric ; (b)tampak samping

\section{KESIMPULAN}

Rasio pada sistem transmisi untuk mobil multiguna pedesaan yang tepat adalah menggunakan 4 tingkat kecepatan dengan spesifikasi tingkat kecepatan ke-1 memiliki nilai 8.4, tingkat kecepatan ke-2 memiliki nilai 4, tingkat kecepatan ke-3 memiliki nilai 2, dan tingkat kecepatan ke-4 memilki nilai 1.

Karakteristik traksi dari sistem transmisi yang ada menunjukkan Traksi maksimal yang dapat dihasilkan oleh sistem adalah sebesar $9504 \mathrm{~N}$ pada tingkat gigi 1, 4525,714 $\mathrm{N}$ pada tingkat gigi 2149,714 $\mathrm{N}$ pada tingkat gigi 3, dan 1018,286 N pada tingkat gigi 4.

Berdasarkan rasio transmisi yang digunakan pada tingkat pertama dengan gaya traksi sebesar $9504 \mathrm{~N}$ kendaraan dapat melewati sudut tanjakan 30 derajat pada kecepatan 9.7 $\mathrm{km} / \mathrm{jam}$ dan kecepatan maksimum yang dapat dicapai kendaraan pada tingkat kecepatan keempat adalah sebesar $69,2 \mathrm{~km} / \mathrm{jam}$.

Berdasarkan Spin area, mode berkendara 2 Wheel Drives baik digunakan pada saat berjalan pada permukaan jalan aspal. Sedangkan saat mode berkendara 4 Wheel Drivers, 
spin area antara ban dan permukaan jalan mengalami kenaikan secara keseluruhan saat berjalan pada permukaan tanah dan lumpur. Selain itu kenaikan nilai spin area juga terjadi saat mobil berjalan pada kondisi jalan yang memiliki gradient kemiringan. Meningkatnya spin area ini tentu meningkatkan keandalan kendaraan saat melewati berbagai macam kondisi jalan dipedesaan karena meminimalisir terjadinya slip pada ban.

Geometri dan Material Spur Gear, Poros, dan Bearing yang akan digunakan dapat dilihat pada gambar assembly

\section{DAFTAR PUSTAKA}

[1] H. Naunheimer, B. Bertsche, J. Ryborz, and W. Novak, Automotive transmissions: Fundamentals, selection, design and application. Berlin, Heidelberg: Springer Berlin Heidelberg, 2011.

[2] I. N. Sutantra and B. Sampurno, Teknologi Otomotif, Edisi Kedua. Surabaya: Guna Widya, 2010.

[3] R. G. Budynas, J. K. Nisbett, and J. E. Shigley, Shigley's mechanical engineering design, 9th. New Delhi: McGraw-Hill, 2011.

[4] A. Deutschman, W. J. Michels, and C. E. Wilson, Machine design : theory and practic. New York: MacMillan Publishers, 1975. 